\title{
How the Soil Microbial Communities and Activities Respond to Long-Term Heavy Metal Contamination in Electroplating Contaminated Site
}

\author{
Wen-Jing Gong ${ }^{1}$, Zi-Fan Niu ${ }^{1}\left(\mathbb{D}\right.$, Xing-Run Wang $^{2}$ and He-Ping Zhao ${ }^{1, *(D)}$ \\ 1 MOE Key Lab of Environmental Remediation and Ecosystem Health, College of Environmental and Resource Sciences, \\ Zhejiang University, Hangzhou 310058, China; gongwenjing@zju.edu.cn (W.-J.G.); zfniu@zju.edu.cn (Z.-F.N.) \\ 2 Chinese Research Academy of Environmental Sciences, Beijing 100012, China; wangxr@craes.org.cn \\ * Correspondence: zhaohp@zju.edu.cn
}

check for updates

Citation: Gong, W.-J.; Niu, Z.-F.; Wang, X.-R.; Zhao, H.-P. How the Soil Microbial Communities and Activities Respond to Long-Term Heavy Metal Contamination in Electroplating Contaminated Site. Microorganisms 2021, 9, 362. https://doi.org/10.3390/ microorganisms 9020362

Academic Editor: Carlos A. Jerez

Received: 13 December 2020

Accepted: 8 February 2021

Published: 12 February 2021

Publisher's Note: MDPI stays neutral with regard to jurisdictional claims in published maps and institutional affiliations.

Copyright: (c) 2021 by the authors. Licensee MDPI, Basel, Switzerland. This article is an open access article distributed under the terms and conditions of the Creative Commons Attribution (CC BY) license (https:/ / creativecommons.org/licenses/by/ $4.0 /)$.

\begin{abstract}
The effects of long-term heavy metal contamination on the soil biological processes and soil microbial communities were investigated in a typical electroplating site in Zhangjiakou, China. It was found that the soil of the electroplating plant at Zhangjiakou were heavily polluted by $\mathrm{Cr}, \mathrm{Cr}(\mathrm{VI})$, $\mathrm{Ni}, \mathrm{Cu}$, and $\mathrm{Zn}$, with concentrations ranged from 112.8 to $9727.2,0$ to $1083.3,15.6$ to $58.4,10.8$ to 510.0 and 69.6 to $631.6 \mathrm{mg} / \mathrm{kg}$, respectively. Soil urease and phosphatase activities were significantly inhibited by the heavy metal contamination, while the microbial biomass carbon content and the bacterial community richness were much lower compared to noncontaminated samples, suggesting that the long-term heavy metal contamination had a severe negative effect on soil microorganisms. Differently, soil dehydrogenase was promoted in the presence of Chromate compared to noncontaminated samples. This might be due to the enrichment of Sphingomonadaceae, which have been proven to be able to secrete dehydrogenase. The high-throughput sequencing of the 16S rRNA gene documented that Proteobacteria, Actinobacteria, and Chloroflexi were the dominant bacterial phyla in the contaminated soil. The Spearman correlation analysis showed the Methylobacillus, Muribaculaceae, and Sphingomonadaceae were able to tolerate high concentrations of $\mathrm{Cr}, \mathrm{Cr}(\mathrm{VI}), \mathrm{Cu}$, and $\mathrm{Zn}$, indicating their potential in soil remediation.
\end{abstract}

Keywords: heavy metals; soil enzyme; microbial biomass carbon; microbial community structure

\section{Introduction}

Heavy metals (HMs) are severe pollutants in soil environments from either natural processes or anthropogenic activities [1]. Electroplating industrial plants are the most common sources of toxic metals by direct or indirect discharge, though they play an important role in the Chinese economy $[2,3]$. The heavy metal waste usually piled up in large quantities, causing a potential threat to the safety of groundwater, soil, and the atmospheric environment [4]. Among them, copper $(\mathrm{Cu})$, zinc $(\mathrm{Zn})$, nickel $(\mathrm{Ni})$, and chromium $(\mathrm{Cr})$ were most common in soil. Thus, the identification of HMs pollution is of significant ecological and anthropic importance.

Soil microbial enzyme activities (EAs) and microbial biomass carbon (MBC), are sensitive to soil ecosystem disturbance [5]. EAs and MBC can reflect the direction and degree of soil biochemical reactions, and serve as potential biological indicators to diagnose soil health [6]. Among enzymes, urease (UA), phosphatase (PHA), and dehydrogenase (DHA) are often used as HMs enzyme markers [5].

Soil microbial community structure and diversity are also highly sensitive to soil environmental changes and are often used as indicators of metal contaminations as well [6]. Many studies have shown the evolution of the microbial community caused by HMs under long-term contamination [7-9]. Song [10] found that the microbial communities changed with $\mathrm{HMs}(\mathrm{Cd}, \mathrm{Cu}, \mathrm{Zn})$ concentrations and soil physicochemical properties $(\mathrm{pH}$, 
$\mathrm{TN}, \mathrm{TC}$ ): while $\mathrm{Li}$ [11] found that $\mathrm{Cr}, \mathrm{Pb}$, and $\mathrm{Zn}$ all negatively affected the abundance of Nitrospirae, Bacteroidetes, and Verrucomicrobia. However, there have been few studies on how the HMs' combined pollution affects microbial community structure, EAs, and MBC at electroplating sites.

In this study, an abandoned electroplating site from Zhangjiakou (Hebei Province, China) was selected for further analysis. The soil environmental parameters, including the concentrations of $\mathrm{Cr}, \mathrm{Cr}(\mathrm{VI}), \mathrm{Ni}, \mathrm{Cu}$, and $\mathrm{Zn}$, were measured. Specifically, the aims of this study were: (i) to explore the relationships among soil HMs contamination, physicochemical properties, soil EAs, MBC, and the structures of the microbial community at in situ electroplating sites; (ii) to predict the possible functions of dominant bacteria in the process of ecological restoration.

\section{Materials and Methods}

\subsection{Study Area}

The Electroplating Plant at Zhangjiakou (EPZ, $\left.40^{\circ} 50^{\prime} 12.008^{\prime \prime} \mathrm{N}, 114^{\circ} 52^{\prime} 26.451^{\prime \prime} \mathrm{E}\right)$ which was used for production since the 1960s, ceased production in 2015. The EPZ lies in the temperate continental monsoon climate zone with an annual mean temperature of $9.6^{\circ} \mathrm{C}$, and multiyear average precipitation of about $350 \mathrm{~mm}[12,13]$. The EPZ includes six electroplating processes located in different areas. The six processes have different HMs concentrations theoretically (Figure S1): location 1 was an electroplating laboratory (S0); location 2 was a chrome bath (S1), location 3 was a decorative chrome tank (S2); location 4 was a postplating treatment room (S3); location 5 was a galvanizing bath (S4), while location 6 was a sewage treatment tank (S5). To reveal the in situ HMs concentration as accurately as possible, we took five samples from different depths in each location. Besides, for comparison with the local soil background value, we collected noncontaminated soil $5 \mathrm{~km}$ away from the plant.

\subsection{Soil Collection}

Thirty soil samples were collected in November 2019 and carried back to the laboratory within $12 \mathrm{~h}$ at $4{ }^{\circ} \mathrm{C}$. All soil samples were divided into two groups, one for molecular genome experiment (stored at $-20^{\circ} \mathrm{C}$ ), another was for physicochemical properties and HMs measurement (air-dried and processed with a $2 \mathrm{~mm}$ sieve to remove the stone and root fragments, stored at $\left.4{ }^{\circ} \mathrm{C}\right)$ [14].

\subsection{Soil Physicochemical and HMs}

The $\mathrm{pH}$ was tested in deionized water at a soil/solution ratio of 1:2.5 using HI 3221 $\mathrm{pH}$ meter from a $2 \mathrm{~mm}$ soil fraction (Seven Easy, Mettler-Toledo, Switzerland). Total contents of $\mathrm{Cr} / \mathrm{Ni} / \mathrm{Cu} / \mathrm{Zn}$ in the soil were analyzed with TAS-990 flame atom adsorption spectrophotometer (Persee Inc., Beijing, China) by digesting $100 \mathrm{mg}$ of soil in a mixture of $\mathrm{HCl}-\mathrm{HNO}_{3}-\mathrm{HF}-\mathrm{HClO}_{4}$, which was constituted with $3 \mathrm{~mL}$ of $1.19 \mathrm{~g} / \mathrm{mL} \mathrm{HCl}, 5 \mathrm{~mL}$ of $1.42 \mathrm{~g} / \mathrm{mL} \mathrm{HNO}_{3}, 5 \mathrm{~mL}$ of $1.49 \mathrm{~g} / \mathrm{mL} \mathrm{HF}, 3 \mathrm{~mL}$ of $1.68 \mathrm{~g} / \mathrm{mL} \mathrm{HClO}_{4}$ and finally constant volume to $50 \mathrm{~mL}$ using deionized water. The digestion program was processed by two stages of heating: $30 \mathrm{~min}$ at $120^{\circ} \mathrm{C}$ and $1 \mathrm{~h}$ at $200{ }^{\circ} \mathrm{C}$ (Persee Inc., Beijing, China). Besides, the total $\mathrm{Cr}(\mathrm{VI})$ concentration of soil samples was measured by alkaline digestion standard method, using a mixture of $50 \mathrm{~mL} \mathrm{NaCO} / \mathrm{NaOH}$ mixed solution, $400 \mathrm{mg} \mathrm{MgCl}$, and $50 \mathrm{~mL} \mathrm{~K}_{2} \mathrm{HPO}_{4}-\mathrm{KH}_{2} \mathrm{PO}_{4}$, and heat at $90-95{ }^{\circ} \mathrm{C}$ for $60 \mathrm{~min}$ [15].

\subsection{Microbial Biomass Carbon and Soil EAs}

Microbial biomass carbon (MBC) was determined by the fumigation-extraction (FE) method [16]. PHA was measured spectrophotometrically by the disodium phenyl phosphate method of Li [17] by measuring the phenolic micrograms per gram of soil. UA activity was determined by the indophenol colorimetric method by measuring $\mathrm{NH}_{4}{ }^{+}-\mathrm{N}$ generated per gram of soil after $24 \mathrm{~h} \mathrm{[18].} \mathrm{DHA} \mathrm{was} \mathrm{tested} \mathrm{by} \mathrm{reduction} \mathrm{of} \mathrm{2,3,5-triphenyltetrazolium}$ chloride (TTC) method [5]. 


\subsection{DNA Extraction and Sequencing}

In this study, we analyzed the bacterial community structure in all soil samples using the Illumina MiSeq PE300 high-throughput sequencing approach. Total genomic DNA was extracted from $0.25 \mathrm{~g}$ of well-mixed soil for each sample using the Power Soil ${ }^{\circledR}$ DNA Isolation Kit (Qiagen, Redwood City, US Functional Area, USA) following the manufacturer's protocol described by Zhao [19-21]. DNA concentration and purity were determined with microspectrophotometry (NanoDrop ${ }^{\circledR}$ ). Extracted DNA was sent to Mingke Biotechnology (Hangzhou) Co., Ltd, amplified with 341F (5'-CCTAYGGGRBGCASCAG-3') and 806R (5'-GGACTACNNGGGTATCTAAT-3') [22,23]. The purified amplicons were then sequenced on an Illumina Miseq sequencing platform. Sequences with $>97 \%$ similarity were assigned to the same operational taxonomic units (OTUs). Representative sequences of each OTU were screened for further annotation [10]. Besides, the $\alpha$-diversity of the bacterial community was determined by the Chao, Shannon, and Simpson indices, and the number of observed species was generated by QIIME2 [24,25].

\subsection{Data Analysis}

The correlation analysis of soil physicochemical, HMs, and microbial activities were completed with the corrplot R package (250 Northern Ave, Boston, MA 02210). Spearman correlation coefficient was calculated with SPSS. Other plots were completed using software Origin (1 Roundhouse Plaza, Northampton, MA, USA).

\section{Results and Discussion}

\subsection{Soil HMs Contamination Level and Physicochemical Properties}

The HMs concentrations of tested soil samples are shown in Table 1. The concentration of total Cr ranged from 112.8 to $9727.2 \mathrm{mg} / \mathrm{kg}$ with an average of $1617.3 \mathrm{mg} / \mathrm{kg}$, while $\mathrm{Cr}$ (VI) ranged from 0 to $1083.3 \mathrm{mg} / \mathrm{kg}$ (average value $111.1 \mathrm{mg} / \mathrm{kg}$ ), Ni varied from 15.6 to $58.4 \mathrm{mg} / \mathrm{kg}$ with mean value of $30.5 \mathrm{mg} / \mathrm{kg}$, Cu and $\mathrm{Zn}$ ranged from 10.8 to $510.0 \mathrm{mg} / \mathrm{kg}$ and 69.6 to $631.6 \mathrm{mg} / \mathrm{kg}$ with an average of $105.5 \mathrm{mg} / \mathrm{kg}$ and $186.8 \mathrm{mg} / \mathrm{kg}$, respectively. Clearly, the concentrations of each HMs were closely related to the electroplating process. For example, the concentrations of $\mathrm{Cr}$ and $\mathrm{Cr}(\mathrm{VI})$ were far higher in S1 (chrome bath) and S2 (decorative chrome tant) (Figure S1) than at the other sites. According to a risk control standard for soil contamination of developing land (GB36600-2018) [26], the concentration of $\mathrm{Cr}$ (VI) severely exceeded the standard ( $3 \mathrm{mg} / \mathrm{kg}$ ) at most sites, while $\mathrm{Cu}$ and $\mathrm{Ni}$ did not exceed the standard (Cu: $2000 \mathrm{mg} / \mathrm{kg}$, Ni: $150 \mathrm{mg} / \mathrm{kg}$ ). The screening value of $\mathrm{Zn}$ differs from province to province, and it is $700 \mathrm{mg} / \mathrm{kg}$ in Hunan province [27]. Thus, Cr pollution became the main contamination in EPZ.

The soil $\mathrm{pH}$ is shown in Table S1. Almost all soil samples were alkaline, except the $\mathrm{S} 2$ sites (lower $\mathrm{pH}$ ranged from 4.24 to 6.23 ), which contained more $\mathrm{Cr}$ and $\mathrm{Cr}$ (VI) than the other sites. Theoretically, as shown in Equation (1), soluble $\mathrm{Cr}$ (VI) will be converted to dissoluble $\mathrm{Cr}$ (III) by $\mathrm{H}^{+}$under acid conditions, and with the decrease in $\mathrm{pH}$, more precipitated $\mathrm{Cr}$ (III) is generated [28,29]. However, the $\mathrm{pH}$ was negatively correlated with the concentrations of $\mathrm{Cr}$ and $\mathrm{Cr}(\mathrm{VI})$ in this study $(\mathrm{Cr}, \mathrm{r}=-0.94, p<0.01 ; \mathrm{Cr}(\mathrm{VI}), \mathrm{r}=-0.91$, $p<0.01$ ) through Pearson Correlation Analysis (Figure 1). Taking human factors into consideration, as shown in Equation (2), sulfuric acid and potassium dichromate were used in the decorative chrome plating process (heating to generate chromium trioxide, which was the raw material), the leakage of which may cause a lower $\mathrm{pH}$ and higher $\mathrm{Cr}$ (VI). The negative correlation between $\mathrm{pH}$ and $\mathrm{Zn}(\mathrm{r}=-0.27, p<0.05)$ concentration is partly due to the adsorption of $\mathrm{Zn}^{2+}$ on oxides and aluminosilicates, which reduced its mobility around $\mathrm{pH}$ 7. The formation or dissolution of a organic $\mathrm{Zn}$ complex at high $\mathrm{pH}$ will weaken the $\mathrm{pH}$ effects on $\mathrm{Zn}$ concentration, but it will not reverse the correlation [30].

$$
\begin{gathered}
\mathrm{Cr}_{2} \mathrm{O}_{7}^{2-}+8 \mathrm{H}^{+}+6 \mathrm{e}^{-}=2 \mathrm{Cr}(\mathrm{OH})_{3}+\mathrm{H}_{2} \mathrm{O} \\
2 \mathrm{H}_{2} \mathrm{SO}_{4}+\mathrm{Na}_{2} \mathrm{Cr}_{2} \mathrm{O}_{7}=2 \mathrm{CrO}_{3}+2 \mathrm{NaHSO}_{4}+\mathrm{H}_{2} \mathrm{O}
\end{gathered}
$$


Meanwhile, $\mathrm{pH}$ was positively correlated with MBC, UA, and PHA (MBC, $r=0.37$, $p<0.05$; UA, $r=0.3, p<0.05$; PHA, $r=0.3, p<0.05)$, and negatively correlated with DHA $(r=-0.65, p<0.01)$. The same result was reported by Wic Baena and JorgeMardomingo [31,32]: $\mathrm{pH}$ had a positive relationship with UA $(r=0.33, p<0.001)$ and PHA $(r=0.43, p<0.001)$ and a negative relationship with DHA $(r=-0.45, p<0.001)$. As shown in Table 2, the $\mathrm{pH}$ was positively correlated with the abundance of Arthrobacter $(r=0.40, p<0.05)$, which have been proved highly active in an alkaline environment [33]. Members of the genus Arthrobacter were found able to secret PHA and UA [34,35]: the positive relationship between $\mathrm{pH}, \mathrm{UA}$, and PHA might be due to the enrichment of Arthrobacter in alkaline environments, thus more PHA and UA were produced.

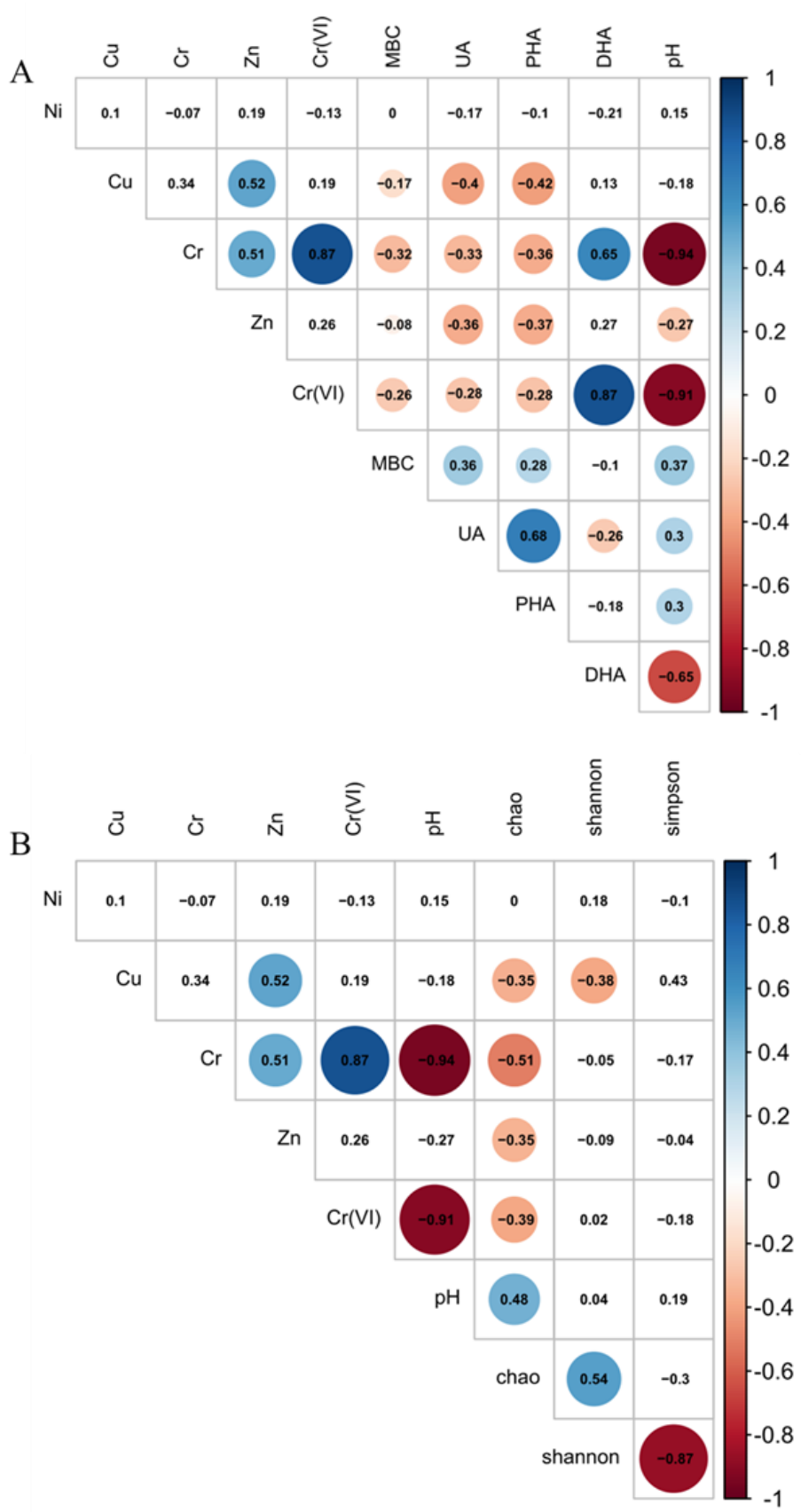

Figure 1. The correlation analysis between the environmental factors and soil microbial activities (A) and $\alpha$-diversity indexes (B) of soil. (Digits represent Pearson correlation coefficients; filled color indicates significant correlation, blue represents positive correlation, red represents negative correlation, shade of color represents strength of correlation). 
Table 1. The heavy mental contents from different sampling sites.

\begin{tabular}{|c|c|c|c|c|c|}
\hline & Total Ni (mg/kg) & Total Cu (mg/kg) & Total Cr (mg/kg) & Total Zn (mg/kg) & Total Cr (VI) (mg/kg) \\
\hline S0-1 & $24.8 \pm 0.72$ & $38.0 \pm 1.04$ & $411.2 \pm 0.72$ & $83.6 \pm 1.20$ & $1.4 \pm 0.28$ \\
\hline S0-2 & $22.0 \pm 0.40$ & $20.0 \pm 0.28$ & $172.4 \pm 0.44$ & $83.6 \pm 0.52$ & $3.2 \pm 0.34$ \\
\hline S0-3 & $28.0 \pm 0.16$ & $29.2 \pm 0.72$ & $232.4 \pm 0.80$ & $105.6 \pm 0.56$ & $1.3 \pm 0.37$ \\
\hline S0-4 & $28.0 \pm 0.52$ & $20.0 \pm 0.04$ & $292.0 \pm 0.68$ & $91.2 \pm 0.16$ & $2.2 \pm 0.22$ \\
\hline S0-5 & $34.0 \pm 1.52$ & $35.2 \pm 0.28$ & $292.0 \pm 0.20$ & $124.8 \pm 0.36$ & $5.0 \pm 0.64$ \\
\hline S1-1 & $30.8 \pm 0.56$ & $16.8 \pm 0.36$ & $292.0 \pm 0.20$ & $96.4 \pm 0.60$ & $6.5 \pm 0.68$ \\
\hline S1-2 & $15.6 \pm 0.20$ & $16.8 \pm 0.16$ & $292.0 \pm 0.36$ & $143.6 \pm 0.40$ & $4.2 \pm 0.20$ \\
\hline S1-3 & $24.8 \pm 0.76$ & $10.8 \pm 0.04$ & $351.6 \pm 0.44$ & $69.6 \pm 0.60$ & $13.0 \pm 0.22$ \\
\hline S1-4 & $30.8 \pm 0.72$ & $486.0 \pm 0.60$ & $5786.0 \pm 7.76$ & $590.4 \pm 0.52$ & $104.5 \pm 2.60$ \\
\hline S1-5 & $24.8 \pm 0.84$ & $16.8 \pm 0.16$ & $351.6 \pm 0.32$ & $165.2 \pm 0.16$ & $82.0 \pm 1.60$ \\
\hline S2-1 & $18.8 \pm 1.12$ & $126.0 \pm 0.08$ & $7338.8 \pm 4.76$ & $258.0 \pm 0.72$ & $302.6 \pm 1.04$ \\
\hline S2-2 & $37.2 \pm 0.40$ & $132.0 \pm 0.12$ & $9727.2 \pm 4.80$ & $245.2 \pm 2.40$ & $861.9 \pm 2.80$ \\
\hline S2-3 & $28.0 \pm 0.52$ & $147.2 \pm 0.28$ & $9249.6 \pm 6.44$ & $251.2 \pm 1.04$ & $861.9 \pm 3.40$ \\
\hline $\mathrm{S} 2-4$ & $22.0 \pm 0.40$ & $219.6 \pm 0.36$ & $6681.6 \pm 3.80$ & $304.4 \pm 0.60$ & $1083.3 \pm 4.40$ \\
\hline S2-5 & $28.0 \pm 0.52$ & $23.2 \pm 0.36$ & $471.2 \pm 0.24$ & $133.2 \pm 1.04$ & $47.5 \pm 1.04$ \\
\hline S3-1 & $30.8 \pm 0.32$ & $258.8 \pm 0.52$ & $530.8 \pm 0.20$ & $156.0 \pm 1.20$ & $3.5 \pm 0.24$ \\
\hline S3-2 & $40.0 \pm 0.28$ & $376.8 \pm 0.64$ & $530.8 \pm 0.24$ & $191.6 \pm 0.24$ & $5.2 \pm 0.04$ \\
\hline S3-3 & $30.8 \pm 0.24$ & $510.0 \pm 1.12$ & $351.6 \pm 0.24$ & $121.6 \pm 1.16$ & $2.3 \pm 0.04$ \\
\hline S3-4 & $28.0 \pm 0.20$ & $86.4 \pm 0.16$ & $351.6 \pm 0.52$ & $98.8 \pm 0.40$ & $3.3 \pm 0.68$ \\
\hline S3-5 & $22.0 \pm 0.76$ & $20.0 \pm 0.08$ & $172.4 \pm 0.44$ & $123.2 \pm 1.64$ & $0.5 \pm 0.44$ \\
\hline S4-1 & $46.4 \pm 0.56$ & $189.2 \pm 0.40$ & $2859.6 \pm 2.48$ & $631.6 \pm 2.08$ & $0.1 \pm 0.20$ \\
\hline S4-2 & $28.0 \pm 0.52$ & $98.8 \pm 0.12$ & $590.4 \pm 0.16$ & $310.0 \pm 2.60$ & $23.3 \pm 0.72$ \\
\hline S4-3 & $40.0 \pm 0.76$ & $92.4 \pm 0.24$ & $590.4 \pm 0.32$ & $327.6 \pm 0.88$ & $1.8 \pm 0.22$ \\
\hline S4-4 & $22.0 \pm 0.72$ & $122.8 \pm 0.76$ & $351.6 \pm 0.72$ & $192.4 \pm 0.88$ & $7.4 \pm 0.80$ \\
\hline S4-5 & $30.8 \pm 0.72$ & $77.6 \pm 3.48$ & $411.2 \pm 0.32$ & $192.4 \pm 0.40$ & $8.4 \pm 0.96$ \\
\hline S5-1 & $24.8 \pm 0.12$ & $16.8 \pm 0.20$ & $112.8 \pm 1.04$ & $128.4 \pm 2.08$ & $3.5 \pm 0.34$ \\
\hline S5-2 & $30.8 \pm 0.56$ & $16.8 \pm 0.16$ & $292.0 \pm 0.36$ & $106.4 \pm 1.80$ & $1.0 \pm 0.28$ \\
\hline S5-3 & $37.2 \pm 0.32$ & $16.8 \pm 0.08$ & $351.6 \pm 0.28$ & $104.0 \pm 0.20$ & $2.1 \pm 0.28$ \\
\hline S5-4 & $58.4 \pm 0.36$ & $20.0 \pm 0.04$ & $232.4 \pm 0.52$ & $98.8 \pm 0.40$ & 0 \\
\hline S5-5 & $34.0 \pm 0.52$ & $10.8 \pm 0.08$ & $172.4 \pm 0.80$ & $148.4 \pm 3.92$ & 0 \\
\hline $\mathrm{NC}$ & $43.2 \pm 0.76$ & $20.0 \pm 0.03$ & $292.0 \pm 0.52$ & $114.8 \pm 0.19$ & 0 \\
\hline
\end{tabular}

Note: The results are presented as mean \pm SD. NC: noncontaminated soil.

Table 2. Spearman correlation coefficient of environmental substrates on bacterial communities.

\begin{tabular}{|c|c|c|c|c|c|c|c|}
\hline & Methylophilaceae_Unclassified & Methylobacillus & Arthrobacter & MB-A2-108_Norank & Vicinamibacterales_Norank & Sphingomonadaceae_Uncultured & Muribaculaceae_Norank \\
\hline $\mathrm{Ni}$ & 0.100 & -0.219 & -0.058 & 0.236 & 0.095 & -0.290 & -0.112 \\
\hline $\mathrm{Cu}$ & 0.107 & 0.132 & -0.266 & -0.152 & -0.157 & 0.250 & $0.363^{*}$ \\
\hline $\mathrm{Cr}$ & -0.338 & 0.294 & -0.285 & $-0.426^{*}$ & -0.377 * & 0.406 * & $0.402 *$ \\
\hline $\mathrm{Zn}$ & -0.345 & 0.259 & -0.246 & $-0.367 *$ & 0.097 & $0.574 * *$ & 0.312 \\
\hline $\mathrm{Cr}$ (VI) & -0.444 * & $0.487 * *$ & -0.278 & -0.500 ** & $-0.416^{*}$ & $0.456^{*}$ & $0.458^{* * *}$ \\
\hline $\mathrm{pH}$ & $0.558^{* * *}$ & -0.167 & 0.404 * & $0.444^{*}$ & 0.393 * & -0.154 & -0.365 * \\
\hline
\end{tabular}

\subsection{Relationship Between HMs, EAs, and MBC}

HMs had a strong influence on the soil EAs and MBC [36]. The EAs concentrations in the soils at different sites were shown in Table S1. As shown in Figure 1A, the EAs and MBC were negatively correlated with nearly all HMs in the electroplating plant.

DHA was very sensitive to HMs contamination and was usually used as an indicator of chromium contamination in soil [37-40]. In this study, DHA was positively correlated with the $\mathrm{Cr}$ and $\mathrm{Cr}(\mathrm{VI})$ concentration (Cr, $r=0.65, p<0.01 ; \mathrm{Cr}(\mathrm{VI}), r=0.87, p<0.01$ ). However, previous studies showed that $\mathrm{Cr}(\mathrm{VI})$ can inhibit DHA activity by over $70 \%$ after $35 \mathrm{~d}$, and DHA activities were the lowest with $0.25 \mathrm{~g} / \mathrm{kg} \mathrm{Cr}$ (VI) [39]. Furthermore, the increase of chromium $\left(\mathrm{K}_{2} \mathrm{Cr}_{2} \mathrm{O}_{7}\right)$ from $40 \mathrm{mg} / \mathrm{kg}$ to $120 \mathrm{mg} / \mathrm{kg}$ caused a decrease of DHA from $2.90 \mathrm{U} / \mathrm{g}$ to $0.25 \mathrm{U} / \mathrm{g}$ [40]. Thus, we assumed that other factors like microbial processes might affect the activity of DHA.

As shown in Table 2, the abundance of Sphingomonadaceae_uncultured increased with $\mathrm{Cr}$ and $\mathrm{Cr}(\mathrm{VI})$ concentration (Cr, $r=0.463, p<0.05$; $\mathrm{Cr}(\mathrm{VI}), r=0.738, p<0.01)$. Since the Sphingomonadaceae family were found to secret DHA [41,42], the positive relationship 
between DHA and $\mathrm{Cr} / \mathrm{Cr}$ (VI) might be that $\mathrm{Cr}$ and $\mathrm{Cr}$ (VI) stimulated the growth of Sphingomonadaceae family which could produce DHA.

PHA usually acts as a catalyst in the hydrolysis of ester and anhydride of phosphoric acid [29]. In present study, PHA was observed negatively correlated to all the metals except $\mathrm{Ni}(\mathrm{Cr}, r=-0.36, p<0.05 ; \mathrm{Cr}(\mathrm{VI}), r=-0.28, p<0.05 ; \mathrm{Cu}, r=-0.42, p<0.05 ; \mathrm{Zn}, r=-0.37$, $p<0.05)$. The UA, which was considered to be closely associated with the transformation, biological turnover, and bioavailability of $\mathrm{N}$ [43], had a negative correlation with $\mathrm{HMs}$ $(\mathrm{Cr}, r=-0.33, p<0.05 ; \mathrm{Cr}(\mathrm{VI}), r=-0.28, p<0.05 ; \mathrm{Zn}, r=-0.36, p<0.05 ; \mathrm{Cu}, r=-0.4$, $p<0.05)$ too. Similar results found that $\mathrm{Cr}, \mathrm{Cr}(\mathrm{VI}), \mathrm{Cu}$, and $\mathrm{Zn}$ had negative correlations with PHA and UA in previous studies [14,44-46]. As shown in Table 2, the $\mathrm{Cr}$ and $\mathrm{Cr}$ (VI) had a negative correlation with Methylophilaceae_Unclassified and Vicinamibacterales_norank. Since they were found to secret PHA and UA [34,47-49], the negative relationship between PHA, UA, and $\mathrm{Cr}, \mathrm{Cr}$ (VI) might be caused by the Methylophilaceae and Vicinamibacterales family members inhibited by $\mathrm{Cr}$ and $\mathrm{Cr}(\mathrm{VI})$.

The microbial biomass of soil is comprised by the total mass of fungi, bacteria, protozoa, and algae [50]. It is usually correlated with the supply of carbon (C) substrate [51]. MBC represents the microbial community size and usually decreased by HMs. Thus, MBC has frequently been used to investigate the long-term impact of HMs on microorganisms within the soil environment [46,52-54]. In our study, MBC was negatively correlated with $\mathrm{Cu}, \mathrm{Cr}$, and $\mathrm{Cr}(\mathrm{VI})(\mathrm{Cu}, r=-0.17, p<0.05 ; \mathrm{Cr}, r=-0.32, p<0.05, \mathrm{Cr}(\mathrm{VI}), r=-0.26, p<0.05)$, and decreased compared to the noncontaminated soils (Table S1). The reason might be that under the HMs pressure, microorganisms spend more energy on detoxification rather than growth and biomass accumulation [55].

\subsection{Relationship between Bacterial Diversity and HMs}

The Illumina MiSeq platform was used to analyze the bacterial diversity of the soil samples across the six contaminated sites. A total of 1,348,872 16S rDNA trimmed sequences with an average length of $416 \mathrm{bp}$ were obtained for classification. The sequences were placed into 60-1778 operational taxonomic units (OTUs) at a level of sequence similarity of $\geq 97 \%$. To compare species richness, rarefaction curves were generated by randomly sampling reads and plotting the number of novel $97 \%$ OTUs against the number of sample size (Figure S2). Clearly, the increase in sample size contributed to an increase in OTUs. As the sample size increased, the curve tended to be flat, indicating a sufficient sequencing data volume.

The bacterial $\alpha$-diversity index is shown in Table S2. It had been reported that longterm contamination with high load $\mathrm{HMs}(\mathrm{Cr}, \mathrm{Cu}$ and $\mathrm{Zn}$ ) could shift the abundance and the diversity of microbial communities [56]. The Chao indices represent the microbial richness and was negatively related to $\mathrm{Cu}, \mathrm{Cr}, \mathrm{Zn}$, and $\mathrm{Cr}$ (VI) $(\mathrm{Cu}, r=-0.35, p<0.05$; $\mathrm{Cr}, \mathrm{r}=-0.51, p<0.01 ; \mathrm{Zn}, \mathrm{r}=-0.35, p<0.05 ; \mathrm{Cr}(\mathrm{VI}), \mathrm{r}=-0.39, p<0.05)$ (Figure 1B) in this study. The same result showing a negative relationship between $\mathrm{Cr}$ and Chao was found in Li's research [11], while there was no evidence supporting relationships among $\mathrm{Ni}, \mathrm{Cu}, \mathrm{Zn}$, and Chao. Furthermore, the Shannon and Simpson indices represented the microbial diversity and only Shannon was negatively correlated with $\mathrm{Cu}(r=-0.38$, $p<0.05)$. As illustrated by Kong, the addition of $\mathrm{Cu}$ up to $100 \mu \mathrm{m}$ strongly reduced functional diversity and evenness of microbial community, suggesting that $\mathrm{Cu}$ was the key factor in reducing microbial diversity [57]. Besides, the bacterial community's richness and diversity decreased significantly compared to the noncontaminated soils. Previous studies showed that the diversity of sensitive microbial species abruptly decreased under longterm HMs contamination, while the abundance of resistant microorganisms increased by adapting to new habitats $[56,58,59]$. This further supported the assumption that the growth of microorganisms was inhibited and the sensitive species might be replaced by resistant species under the pressure of HMs, causing a lower microbial richness and diversity. 


\subsection{Relationship between Bacterial Community and HMs}

By using principal component analysis (PCA), we separated the data of bacterial genus into two factors that explained $74.03 \%$ of the variance (Figure 2). Clearly, the bacterial communities of the S1 site, which contained more Methylobacillus, were totally different from other sites. The other sites (S0, S2, S3, S4 and S5) were grouped tightly, indicating that most of the soil samples shared high similarity in terms of their bacterial structure.

For further analysis, the bacterial community composition of contaminated soils was investigated, and the result is shown in Figure 3A at the phylum level and Figure 3B at the genus level. The phylum shown in the Figure $3 \mathrm{~A}$ is based on the taxa with a total abundance $>30 \%$ of all samples. Besides, the genus shown in the Figure $3 \mathrm{~B}$ is based on the taxa with a total abundance $>30 \%$ of all samples, and abundance $>10 \%$ in at least one sample. The Actinobacteria and Proteobacteria were the dominant phyla in all samples except S2-2 and S2-3, while Chloroflexi, Firmicutes, Acidobacteria, Patescibacteria, and Gemmatimonadota accounted for a small amount proportion. At the genus level, the Methylophilaceae_Unclassified, Methylobacillus, Arthrobactery and Muribaculaceae_norank, belonged to Proteobacteria and Actinobacteria dominated the microbial communities in soil samples S0, S1, S2, S3 and S4. Besides, the Actinobacteria was dominant in the noncontaminated soils, while the Proteobacteria was dominant in the contaminated soils. Similarly, Sheik found that the contaminated soils all had a similar phylum-level abundance, and Proteobacteria was the dominant phylum in $\mathrm{Cr}$ contaminated soils in contrast to the control soils where Actinobacteria was the dominant phylum [60]. This suggested that the genus that belonged to Proteobacteria had more resistance towards HMs than that belonging to Actinobacteria.

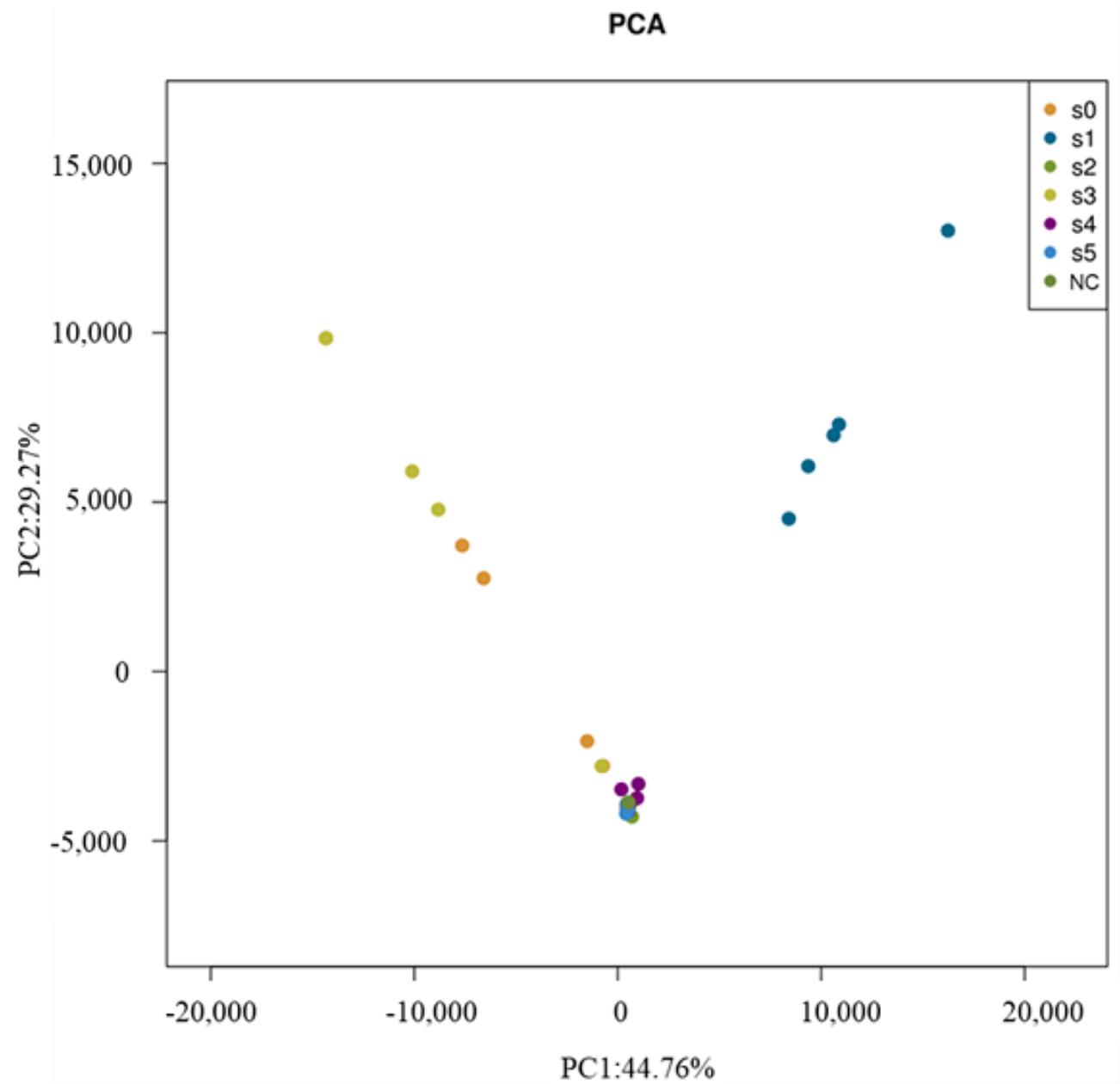

Figure 2. Principal component analysis for the bacterial $16 \mathrm{~S}$ rDNA sequences. (NC: noncontaminated soil). 
The effects of HMs on bacteria community structure have been widely studied previously [61-63]. In this study, we investigated the relationships between HMs and some bacterial genus in EPZ soil samples, as shown in Table 2. We found that Sphingomonadaceae_uncultured was positively correlated with $\mathrm{Cr}(r=0.406, p<0.05), \mathrm{Zn}(r=0.574, p<0.05)$ and $\mathrm{Cr}(\mathrm{VI})$ $(r=0.456, p<0.01)$.

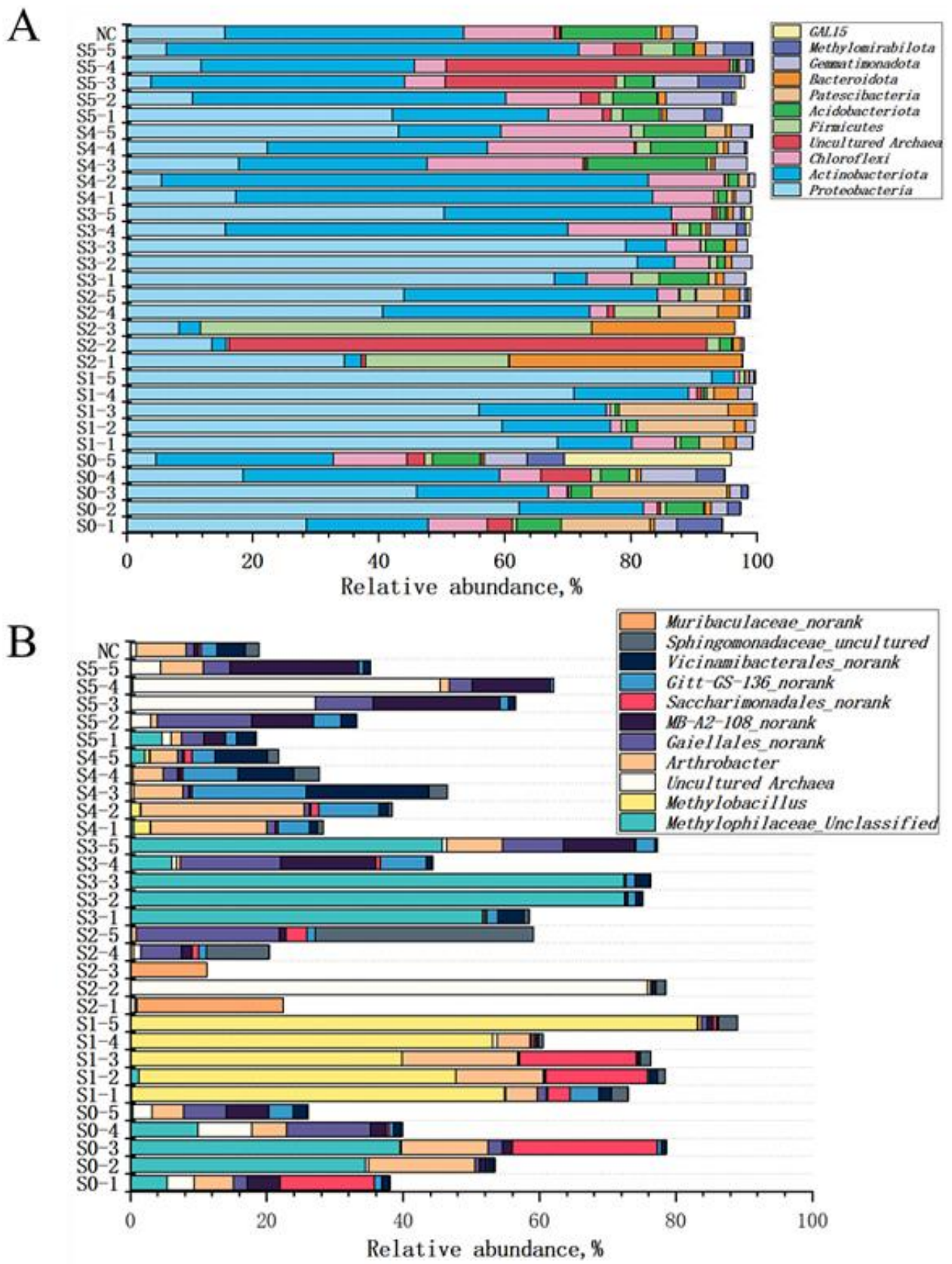

Figure 3. Community composition of bacteria phylum (A) and genus (B) in the soil. (NC: noncontaminated soil).

Downstream genes $\operatorname{osc} A$, which were found to resistant to $\mathrm{Cr}$ (VI), were proved to exist in Methylobacillus, suggesting that Methylobacillus may be related to Cr (VI) resistance [64]. Zhou reported that the abundance of Sphingomonadaceae increased with $\mathrm{CrO}_{4}{ }^{2-}$ exposure and became the major bacteria in the cake layer of a membrane bioreactor [65]. Liu showed that Sphingomonadaceae was significantly enriched at an $80 \mathrm{~cm}$ depth layer in chromiumcontaminated soil [66]. Besides the Sphingomonadaceae was found dominated in many soils polluted with Zn, Cr and related to the Zn hyperaccumulation in the root $[63,67,68]$, 
suggesting that Sphingomonadaceae might have a resistance to $\mathrm{Cr}, \mathrm{Cr}$ (VI) and Zn, and might help $\mathrm{Cr}$ (VI) contaminated soil to recover ecological function. There were few research pieces focusing on the Muribaculaceae, and our result showed a positive correlation between Muribaculaceae and HMs, suggesting that it might have a strong resistance towards $\mathrm{Cr}$, $\mathrm{Cr}(\mathrm{VI})$, and $\mathrm{Cu}$, which had never been found before.

\section{Conclusions}

This study showed that DHA was significant positively correlated with $\mathrm{Cr}$ and $\mathrm{Cr}$ (VI) in contaminated soil, which had never been found in previous studies. High-throughput sequencing results verified that Sphingomonadaceae, which had been proved to be able to secrete DHA, was enriched in Cr contaminated soils. Meanwhile, the microorganism might divert energy from growth to cell maintenance functions under HMs pressure, causing a decrease in the richness of the bacterial community and MBC. Besides, Methylobacillus and Muribaculaceae might have strong resistance to $\mathrm{Cr}$ (VI), $\mathrm{Zn}$, and $\mathrm{Cu}$ meaning these microbes might have advantages and potential applications in the bioremediation of heavy metal compound contaminated soils.

Supplementary Materials: The following are available online at https:/ /www.mdpi.com/2076-260 7/9/2/362/s1, Figure S1: The location of sampling sites; Figure S2: Rarefaction curves for the number of OTUs with more than $97 \%$ similarity threshold; Table S1: The soil PH and enzyme activities with different sampling sites; Table S2: The soil $\alpha$-diversity with different sampling sites.

Author Contributions: Conceptualization, H.-P.Z.; formal analysis, W.-J.G., Z.-F.N.; X.R.-W.; investigation, W.-J.G., Z.-F.N.; methodology, W.-J.G.; project administration, H.-P.Z.; resources, X.-R.W.; writing-review and editing, H.-P.Z. All authors have read and agreed to the published version of the manuscript.

Funding: Natural Science Funds for Distinguished Young Scholar of Zhejiang Province: LR17B070001. National Key Technology R\&D Program: 2018YFC1802203. National Natural Science Foundation of China: 51878596, 21577123.

Institutional Review Board Statement: Not applicable.

Informed Consent Statement: Not applicable.

Data Availability Statement: The data presented in this study are available on request from the corresponding author.

Acknowledgments: The authors greatly thank the "National Key Technology R\&DProgram (2018YFC1802203)", the "Natural Science Funds for Distinguished Young Scholar of Zhejiang Province (LR17B070001)", and the "National Natural Science Foundation of China (Grant No. 51878596, 21577123)", for their financial support.

Conflicts of Interest: The authors declare no conflict of interest.

\section{References}

1. Hang, X.; Wang, H.; Zhou, J.; Du, C.; Chen, X. Characteristics and accumulation of heavy metals in sediments originated from an electroplating plant. J. Hazard. Mater. 2009, 163, 922-930. [CrossRef]

2. Liu, J.; Zhang, X.H.; Tran, H.; Wang, D.Q.; Zhu, Y.N. Heavy metal contamination and risk assessment in water, paddy soil, and rice around an electroplating plant. Environ. Sci. Pollut. Res. 2011, 18, 1623-1632. [CrossRef]

3. Jordao, C.P.; Pereira MD, G.; Einloft, R.; Santana, M.B.; Bellato, C.R.; Vargas de Mello, J.W. Removal of Cu, Cr, Ni, Zn, and Cd from electroplating wastes and synthetic solutions by vermicompost of cattle manure. J. Environ. Sci. Health 2002, 37, 875-892. [CrossRef] [PubMed]

4. Kim, T.; Kim, T.K.; Zoh, K.D. Removal mechanism of heavy metal $(\mathrm{Cu}, \mathrm{Ni}, \mathrm{Zn}$, and $\mathrm{Cr})$ in the presence of cyanide during electrocoagulation using Fe and Al electrodes. J. Water Process. Eng. 2020, 33, 101-109. [CrossRef]

5. Pan, J.; Yu, L. Effects of Cd or/and Pb on soil enzyme activities and microbial community structure. Ecol. Eng. 2011, 37, 1889-1894. [CrossRef]

6. Tang, J.; Zhang, J.; Ren, L.; Zhou, Y.; Gao, J.; Luo, L.; Chen, A. Diagnosis of soil contamination using microbiological indices: A review on heavy metal pollution. J. Environ. Manag. 2019, 242, 121-130. [CrossRef] [PubMed]

7. Wang, Y.; Peng, B.; Yang, Z.; Chai, L.; Liao, Q.; Zhang, Z.; Li, C. Bacterial community dynamics during bioremediation of Cr (VI)-contaminated soil. Appl. Soil Ecol. 2015, 85, 50-55. [CrossRef] 
8. Wang, N.; Zhang, S.; He, M. Bacterial community profile of contaminated soils in a typical antimony mining site. Environ. Sci. Pollut. Res. 2018, 25, 141-152. [CrossRef] [PubMed]

9. Lin, Y.; Ye, Y.; Hu, Y.; Shi, H. The variation in microbial community structure under different heavy metal contamination levels in paddy soils. Ecotoxicol. Environ. Saf. 2019, 180, 557-564. [CrossRef]

10. Song, J.; Shen, Q.; Wang, L.; Qiu, G.; Shi, J.; Xu, J.; Liu, X. Effects of Cd, Cu, Zn and their combined action on microbial biomass and bacterial community structure. Environ. Pollut. 2018, 243, 510-518. [CrossRef] [PubMed]

11. Li, C.; Quan, Q.; Gan, Y.; Dong, J.; Fang, J.; Wang, L.; Liu, J. Effects of heavy metals on microbial communities in sediments and establishment of bioindicators based on microbial taxa and function for environmental monitoring and management. Sci. Total Environ. 2020, 749, 141-555. [CrossRef]

12. Huang, A.; Xu, Y.; Sun, P.; Zhou, G.; Liu, C.; Lu, L.; Wang, H. Land use/land cover changes and its impact on ecosystem services in ecologically fragile zone: A case study of Zhangjiakou City, Hebei Province, China. Ecol. Indic. 2019, 104, 604-614. [CrossRef]

13. Liu, C.; Gong, Z.; Teo, K.L.; Sun, J.; Caccetta, L. Robust multi-objective optimal switching control arising in 1, 3-propanediol microbial fed-batch process. Nonlinear Anal. Hybrid. Syst. 2017, 25, 1-20. [CrossRef]

14. Wang, Y.; Shi, J.; Wang, H.; Lin, Q.; Chen, X.; Chen, Y. The influence of soil heavy metals pollution on soil microbial biomass, enzyme activity, and community composition near a copper smelter. Ecotoxicol. Environ. Saf. 2007, 67, 75-81. [CrossRef] [PubMed]

15. Han, X.; Wong, Y.S.; Wong, M.H.; Tam, N.F.Y. Biosorption and bioreduction of Cr (VI) by a microalgal isolate, Chlorella miniata. J. Hazard. Mater. 2007, 146, 65-72. [CrossRef] [PubMed]

16. Vance, E.D.; Brookes, P.C.; Jenkinson, D.S. An extraction method for measuring soil microbial biomass C. Soil Biol. Biochem. 1987, 19, 703-707. [CrossRef]

17. Li, F.D. Analysis of soil enzyme activity. In Experimental Techniques in Agricultural Microbiology; Chinese Agricultural Press: Beijing, China, 1996; pp. 137-139.

18. Kandeler, E.; Gerber, H. Short-term assay of soil urease activity using colorimetric determination of ammonium. Biol. Fertil. Soils 1988, 6, 68-72. [CrossRef]

19. Zhao, H.P.; Ontiveros-Valencia, A.; Tang, Y.; Kim, B.O.; Ilhan, Z.E.; Krajmalnik-Brown, R.; Rittmann, B. Using a two-stage hydrogen-based membrane biofilm reactor (MBfR) to achieve complete perchlorate reduction in the presence of nitrate and sulfate. Environ. Sci. Technol. 2013, 47, 1565-1572. [CrossRef] [PubMed]

20. Ontiveros-Valencia, A.; Tang, Y.; Zhao, H.P.; Friese, D.; Overstreet, R.; Smith, J.; Krajmalnik-Brown, R. Pyrosequencing analysis yields comprehensive assessment of microbial communities in pilot-scale two-stage membrane biofilm reactors. Environ. Sci. Technol. 2014, 48, 7511-7518. [CrossRef] [PubMed]

21. Chen, R.; Luo, Y.H.; Chen, J.X.; Zhang, Y.; Wen, L.L.; Shi, L.D.; Zhao, H.P. Evolution of the microbial community of the biofilm in a methane-based membrane biofilm reactor reducing multiple electron acceptors. Environ. Sci. Pollut. Res. 2016, 23, 9540-9548. [CrossRef] [PubMed]

22. Li, W.; Lin, X.Y.; Chen, J.J.; Cai, C.Y.; Abbas, G.; Hu, Z.Q.; Zheng, P. Enrichment of denitratating bacteria from a methylotrophic denitrifying culture. Appl. Microbiol. Biotechnol. 2016, 100, 10203-10213. [CrossRef]

23. Zhou, C.; Wang, Z.; Ontiveros-Valencia, A.; Long, M.; Lai, C.Y.; Zhao, H.P.; Rittmann, B.E. Coupling of Pd nanoparticles and denitrifying biofilm promotes $\mathrm{H} 2$-based nitrate removal with greater selectivity towards N2. Appl. Catal. B Environ. 2017, 206, 461-470. [CrossRef]

24. Lai, C.Y.; Dong, Q.Y.; Rittmann, B.E.; Zhao, H.P. Bioreduction of antimonate by anaerobic methane oxidation in a membrane biofilm batch reactor. Environ. Sci. Technol. 2018, 52, 8693-8700. [CrossRef] [PubMed]

25. Lai, C.Y.; Lv, P.L.; Dong, Q.Y.; Yeo, S.L.; Rittmann, B.E.; Zhao, H.P. Bromate and nitrate bioreduction coupled with poly- $\beta$ hydroxybutyrate production in a methane-based membrane biofilm reactor. Environ. Sci. Technol. 2018, 52, 7024-7031. [CrossRef] [PubMed]

26. Li, T.; Liu, Y.; Lin, S.; Liu, Y.; Xie, Y. Soil pollution management in china: A brief introduction. Sustainability 2019, 11, 556. [CrossRef]

27. Sun, Y.; Li, H.; Guo, G.; Semple, K.T.; Jones, K.C. Soil contamination in China: Current priorities, defining background levels and standards for heavy metals. J. Environ. Manag. 2019, 251. [CrossRef] [PubMed]

28. Zeng, F.; Ali, S.; Zhang, H.; Ouyang, Y.; Qiu, B.; Wu, F.; Zhang, G. The influence of $\mathrm{pH}$ and organic matter content in paddy soil on heavy metal availability and their uptake by rice plants. Environ. Pollut. 2011, 159, 84-91. [CrossRef]

29. Pattnaik, B.K.; Equeenuddin, S.M. Potentially toxic metal contamination and enzyme activities in soil around chromite mines at Sukinda Ultramafic Complex, India. J. Geochem. Explor. 2016, 168, 127-136. [CrossRef]

30. Tyler, G.; Olsson, T. Concentrations of 60 elements in the soil solution as related to the soil acidity. Eur. J. Soil Sci. 2001, 52, 151-165. [CrossRef]

31. Baena, C.W.; Andrés-Abellán, M.; Lucas-Borja, M.E.; Martínez-García, E.; García-Morote, F.A.; Rubio, E.; López-Serrano, F.R Thinning and recovery effects on soil properties in two sites of a Mediterranean forest, in Cuenca Mountain (South-eastern of Spain). For. Ecol. Manag. 2013, 308, 223-230. [CrossRef]

32. Jorge, I.; Soler, P.; Casermeiro, M.Á.; Cruz, M.T.; Polo, A. Seasonal changes in microbial activity in a semiarid soil after application of a high dose of different organic amendments. Geoderma 2013, 206, 40-48. [CrossRef]

33. De Prada, P.; Brenchley, J.E. Purification and characterization of two extracellular alkaline phosphatases from a psychrophilic arthrobacter isolate. Appl. Environ. Microbiol. 1997, 63, 2928-2931. [CrossRef] 
34. Heyrman, J.; Verbeeren, J.; Schumann, P.; Swings, J.; De Vos, P. Six novel Arthrobacter species isolated from deteriorated mural paintings. Int. J. Syst. Evol. Microbiol. 2005, 55, 1457-1464. [CrossRef]

35. Li, Y.T.; Zhang, H.H.; Sheng, H.M.; An, L.Z. Cloning, expression and characterization of trehalose-6-phosphate phosphatase from a psychrotrophic bacterium, Arthrobacter strain A3. World J. Microbiol. Biotechnol. 2012, 28, 2713-2721. [CrossRef]

36. Aponte, H.; Herrera, W.; Cameron, C.; Black, H.; Meier, S.; Paolini, J.; Cornejo, P. Alteration of enzyme activities and functional diversity of a soil contaminated with copper and arsenic. Ecotoxicol. Environ. Saf. 2020, 192-200. [CrossRef]

37. Mikanova, O. Effects of heavy metals on some soil biological parameters. J. Geochem. Explor. 2006, 88, 220-223. [CrossRef]

38. Kumar, S.; Chaudhuri, S.; Maiti, S.K. Soil dehydrogenase enzyme activity in natural and mine soil-a review. Middle East. J. Sci. Res. 2013, 13, 898-906.

39. Peng, B.; Huang, S.H.; Yang, Z.H.; Chai, L.Y.; Xu, Y.Z.; Su, C.Q. Inhibitory effect of Cr (VI) on activities of soil enzymes. J. Cent. South Univ. Technol. 2009, 16, 594-598. [CrossRef]

40. Wyszkowska, J.; Kucharski, J.; Jastrzebska, E.; Hlasko, A. The biological properties of soil as influenced by chromium contamination. Pol. J. Environ. Stud. 2001, 10, 37-42.

41. Zeiser, J.; Mühlenbeck, L.H.; Schweiger, P.; Deppenmeier, U. Characterization of a periplasmic quinoprotein from Sphingomonas wittichii that functions as aldehyde dehydrogenase. Appl. Microbiol. Biotechnol. 2014, 98, 2067-2079. [CrossRef] [PubMed]

42. Bastida, F.; Jehmlich, N.; Lima, K.; Morris BE, L.; Richnow, H.H.; Hernández, T.; García, C. The ecological and physiological responses of the microbial community from a semiarid soil to hydrocarbon contamination and its bioremediation using compost amendment. J. Proteom. 2016, 135, 162-169. [CrossRef]

43. Liang, Y.; Yang, Y.; Yang, C.; Shen, Q.; Zhou, J.; Yang, L. Soil enzymatic activity and growth of rice and barley as influenced by organic manure in an anthropogenic soil. Geoderma 2003, 115, 149-160. [CrossRef]

44. Wu, P.; Zhang, L.; Liu, Y.; Xie, X.; Zhou, J.; Jia, H.; Wei, P. Enhancing Cu-Zn-Cr-Ni Co-extraction from electroplating sludge in acid leaching process by optimizing $\mathrm{Fe}^{3+}$ addition and redox potential. Environ. Eng. Sci. 2019, 36, 1244-1257. [CrossRef]

45. Samborska, A.; Stepniewska, Z.; Stepniewski, W. Influence of different oxidation states of chromium (VI, III) on soil urease activity. Geoderma 2004, 122, 317-322. [CrossRef]

46. Hu, X.F.; Jiang, Y.; Shu, Y.; Hu, X.; Liu, L.; Luo, F. Effects of mining wastewater discharges on heavy metal pollution and soil enzyme activity of the paddy fields. J. Geochem. Explor. 2014, 147, 139-150. [CrossRef]

47. Huber, K.J.; Overmann, J. Luteitalea. In Bergey's Manual of Systematics of Archaea and Bacteria; John Wiley \& Sons, Inc., in Association with Bergey's Manual Trust: Hoboken, NJ, USA, 2015; pp. 1-5.

48. Sheu, C.; Cai, C.Y.; Sheu, S.Y.; Li, Z.H.; Chen, W.M. Pseudomethylobacillus aquaticus gen. nov., sp. nov., a new member of the family Methylophilaceae isolated from an artificial reservoir. Int. J. Syst. Evol. Microbiol. 2019, 69, 3551-3559. [CrossRef] [PubMed]

49. Editorial Board. Methylophilus. In Bergey's Manual of Systematics of Archaea and Bacteria; John Wiley \& Sons, Inc., in Association with Bergey's Manual Trust: Hoboken, NJ, USA, 2015; pp. 1-3.

50. Charlton, A.; Sakrabani, R.; Tyrrel, S.; Casado, M.R.; McGrath, S.P.; Crooks, B.; Campbell, C.D. Long-term impact of sewage sludge application on soil microbial biomass: An evaluation using meta-analysis. Environ. Pollut. 2016, 219, 1021-1035. [CrossRef]

51. Liu, X.M.; Qi, L.I.; Liang, W.J.; Jiang, Y. Distribution of soil enzyme activities and microbial biomass along a latitudinal gradient in farmlands of Songliao Plain, Northeast China. Pedosphere 2008, 18, 431-440. [CrossRef]

52. Yu, Z.; Li, Y.; Wang, G.; Liu, J.; Liu, J.; Liu, X.; Herbert, S.J.; Jin, J. Effectiveness of elevated $\mathrm{CO}_{2}$ mediating bacterial communities in the soybean rhizosphere depends on genotypes. Agric. Ecosyst. Environ. 2016, 231, 229-232. [CrossRef]

53. Zhang, C.; Nie, S.; Liang, J.; Zeng, G.; Wu, H.; Hua, S.; Xiang, H. Effects of heavy metals and soil physicochemical properties on wetland soil microbial biomass and bacterial community structure. Sci. Total Environ. 2016, 557, 785-790. [CrossRef]

54. Abaye, D.A.; Lawlor, K.; Hirsch, P.R.; Brookes, P.C. Changes in the microbial community of an arable soil caused by long-term metal contamination. Eur. J. Soil Sci. 2005, 56, 93-102. [CrossRef]

55. Muhammad, A.; Xu, J.; Li, Z.; Wang, H.; Yao, H. Effects of lead and cadmium nitrate on biomass and substrate utilization pattern of soil microbial communities. Chemosphere 2005, 60, 508-514. [CrossRef]

56. Xu, Y.; Seshadri, B.; Sarkar, B.; Wang, H.; Rumpel, C.; Sparks, D.; Bolan, N. Biochar modulates heavy metal toxicity and improves microbial carbon use efficiency in soil. Sci. Total Environ. 2018, 621, 148-159. [CrossRef] [PubMed]

57. Kong, W.D.; Zhu, Y.G.; Fu, B.J.; Marschner, P.; He, J.Z. The veterinary antibiotic oxytetracycline and Cu influence functional diversity of the soil microbial community. Environ. Pollut. 2006, 143, 129-137. [CrossRef]

58. Zhao, X.; Huang, J.; Lu, J.; Sun, Y. Study on the influence of soil microbial community on the long-term heavy metal pollution of different land use types and depth layers in mine. Ecotoxicol. Environ. Saf. 2019, 170, 218-226. [CrossRef]

59. De Oliveira, A.J.F.C.; Hollnagel, H.C.; Mesquita, H.D.S.L.; Fontes, R.F.C. Physical, chemical and microbiological characterization of the intertidal sediments of Pereque Beach, Guarujá (SP), Brazil. Mar. Pollut. Bull. 2007, 54, 921-927. [CrossRef] [PubMed]

60. Sheik, C.S.; Mitchell, T.W.; Rizvi, F.Z.; Rehman, Y.; Faisal, M.; Hasnain, S.; Krumholz, L.R. Exposure of soil microbial communities to chromium and arsenic alters their diversity and structure. PLOS ONE 2012, 7, 40-59.

61. Schneider, A.R.; Gommeaux, M.; Duclercq, J.; Fanin, N.; Conreux, A.; Alahmad, A.; Marin, B. Response of bacterial communities to $\mathrm{Pb}$ smelter pollution in contrasting soils. Sci. Total Environ. 2017, 605, 436-444. [CrossRef] [PubMed]

62. Wang, C.; Jiang, K.; Zhou, J.; Liu, J.; Wu, B. Responses of soil N-fixing bacterial communities to redroot pigweed (Amaranthus retroflexus L.) invasion under $\mathrm{Cu}$ and Cd heavy metal soil pollution. Agric. Ecosyst. Environ. 2018, 267, 15-22. [CrossRef] 
63. Li, Q.; You, P.; Hu, Q.; Leng, B.; Wang, J.; Chen, J.; Ouyang, K. Effects of co-contamination of heavy metals and total petroleum hydrocarbons on soil bacterial community and function network reconstitution. Ecotoxicol. Environ. Saf. 2020, 204-213. [CrossRef] [PubMed]

64. Viti, C.; Decorosi, F.; Mini, A.; Tatti, E.; Giovannetti, L. Involvement of the oscA gene in the sulphur starvation response and in Cr (VI) resistance in Pseudomonas corrugata 28. Microbiology 2009, 155, 95-105. [CrossRef] [PubMed]

65. Zhou, L.; Ye, B.; Xia, S. Structural characteristics of cake layer in membrane bioreactor with chromate exposure. Ecotoxicol. Environ. Saf. 2019, 169, 583-589. [CrossRef] [PubMed]

66. Liu, B.; Su, G.; Yang, Y.; Yao, Y.; Huang, Y.; Hu, L.; He, Z. Vertical distribution of microbial communities in chromium-contaminated soil and isolation of Cr (VI)-Reducing strains. Ecotoxicol. Environ. Saf. 2019, 180, 242-251. [CrossRef] [PubMed]

67. Luo, J.; Tao, Q.; Wu, K.; Li, J.; Qian, J.; Liang, Y.; Li, T. Structural and functional variability in root-associated bacterial microbiomes of Cd/Zn hyperaccumulator Sedum alfredii. Appl. Microbiol. Biotechnol. 2017, 101, 7961-7976. [CrossRef] [PubMed]

68. Li, S.; Wu, J.; Huo, Y.; Zhao, X.; Xue, L. Profiling multiple heavy metal contamination and bacterial communities surrounding an iron tailing pond in Northwest China. Sci. Total Environ. 2020, 752-761. [CrossRef] 